\title{
Relevance of Bcl-x expression in different types of endometrial tissues
}

Xiaoxin Ma ${ }^{1 *}$, Yanhui Zhao ${ }^{2}$, Yanxia Li ${ }^{2}$, Hongwei Lu' ${ }^{2}$ Yuanqi $\mathrm{He}^{2}$

\begin{abstract}
Objectives: To explore the roles of $\mathrm{BCl}-\mathrm{xl}$ and $\mathrm{BCl}-\mathrm{xs}$ in the development and progression of endometrial carcinoma, and to analyze the correlation between Bcl-xl and Bcl-xs.

Methods: RT-PCR and Western-blot assay were applied to detect the expressions of BCl-xl and BCl-xs in endometrial tissues of various histomorphologic types.

Results: The Bcl-xl expression levels of simple and atypical hyperplasia endometrial tissues were not significantly different from that of normal endometrial tissue (both $P>0.05$ ). On contrary, Bcl-xl expression in endometrial carcinoma tissue was significantly higher than the normal endometrial tissue $(P=0.00)$, which was correlated with the pathological grading of endometrial carcinoma ( $F=5.33, P=0.02$ ). In addition, $B c l-x s$ mRNA level in simple hyperplasia endometrial tissue had no significant difference compared to that in normal endometrial tissue $(P=$ 0.12), while the levels of atypical hyperplasia and endometrial carcinoma endometrial tissues were significantly different from the normal endometrial tissue (both $P=0.00$ ). Furthermore, level of $\mathrm{BCl}$-xs mRNA was correlated with the clinical staging and lymph node metastasis of the endometrial carcinoma $(P<0.05)$. The expressions of $\mathrm{BCl}-\mathrm{xl}$ and $\mathrm{BCl}-\mathrm{xs}$ were negatively correlated with each other $(r=-0.76)$.
\end{abstract}

Conclusion: The abnormal expressions of Bcl-xs and Bcl-xl were one of the molecular mechanisms for the pathogenesis of endometrial carcinoma, and altered ratio between these two might involve in the onset of endometrial carcinoma.

\section{Introduction}

Endometrial carcinoma is one of the common malignant tumors of female genital tract. The incidence of endometrial carcinoma continued to increase annually and it has replaced cervical cancer in some countries as the most common malignant tumors of female genital tract [1]. However, the molecular biological mechanisms involved in the pathogenesis of endometrial carcinoma remain unclear. Recent studies find that Bcl-2 family is a major tumor suppressor gene family in association to the pathogenesis of endometrial carcinoma. As a regulatory point for caspase activation and mitochondria function, Bcl-2 gene family functions as a common pathway for transmission of cell apoptosis signals to regulate cell survival and apoptosis[2]. There are at least 15 members in the Bcl-2 family[3,4], among which Bcl-2 and Bcl-x are major genes involving in the development and

\footnotetext{
* Correspondence: maxiaoxin666@yahoo.com.cn

'Department of Obstetrics \& Gynecology, Shengjing Hospital of China Medical University, Shenyang(110004), China
}

progression of tumors and therefore attract much attentions. $\mathrm{Bcl}-\mathrm{xl}$ and $\mathrm{Bcl}-\mathrm{xs}$ are encoded by $\mathrm{Bcl}-\mathrm{x}$ gene, where the abnormal expression of such in various tumors including breast cancer, multiple myeloma and thyroid cancer etc. has been reported in many domestic and foreign literatures[5-7]. However, few report has shown the levels of $\mathrm{Bcl}-\mathrm{xl}$ and $\mathrm{Bcl}-\mathrm{xs}$ in endometrial carcinoma tissue. The objective of this study was to investigate the roles of $\mathrm{Bcl}-\mathrm{xl}$ and $\mathrm{Bcl}-\mathrm{xs}$ in the development and progression of endometrial carcinoma.

\section{Materials and methods \\ Material}

Experimental group included endometrial tissues from 50 patients, who underwent surgery or hysteroscopy for suspected endometrial lesions in the Department of Obstetrics and Gynecology department in Shengjing Hospital of China Medical University from December 2005 to October 2006, including 6 cases of simple hyperplasia, 12 cases of atypical hyperplasia and 
32 cases of endometrial carcinoma. Tissues with endometrial lesions were extracted for subsequent experiments. Control group included normal endometrial tissues from patients who underwent hysterectomy for carcinoma of the cervix, including tissues in proliferative phase (6 cases) and tissues in secretory phase(4 cases), total of 10 cases. Patients in experimental group aged $34 \sim 70$ years old with an average age of $52 \pm 5.04$ years old, while the range of ages in control group was $37 \sim 59$ years old with an average age of $48 \pm 2.13$ years old. Patients did not receive radiotherapy, chemotherapy or hormone therapy before the surgery and all cases were confirmed by histopathology. 32 cases of endometrial carcinoma were graded for surgical and pathologic stages according to the criteria in FIGO 1988: 22 cases of stage I, 4 cases of stage II and 6 cases of stage III endometrial carcinoma. Histological grading: 14 cases of G1, 12 cases of G2 and 6 cases of G3 for endometrial carcinoma. Myometrial invasion classification: 10 cases in stage Ia, 16 cases in stage Ib and 6 cases in stage Ic. Patients were also grouped according to the status of lymph node metastasis: 6 cases with lymph node metastasis and 26 cases free of lymph node metastasis.

\section{Methods \\ $R T-P C R$ technique to detect the expressions of $B C l-x l$ and Bcl-xs mRNA}

Total tissue RNA was extracted by following protocol provided in the TRIzol reagent kit (DaLian TAKARA Biotechnology Company). The $1^{\text {st }}$ strand of cDNA was synthesized according to protocol provided in the Reverse Transcription kit (Shanghai Invitrogen Biotechnology Co. Ltd.), while using a total of $15 \mu \mathrm{l}$ of reaction system with $1.5 \mu$ l template RNA. The cDNA product was stored at $-20^{\circ} \mathrm{C}$ for experiments. $\beta$-actin was included as an internal control and PCR assay was performed to amplify target genes. The volume of PCR reaction system was $25 \mu \mathrm{l}: 3 \mu \mathrm{l}$ template cDNA, $2.5 \mu \mathrm{l} 10 \times$ buffer, $2 \mu \mathrm{l} 2.5 \mathrm{mM}$ dNTP, $0.1 \mu \mathrm{l}$ of each primers, and $0.2 \mu \mathrm{l}$ $5 \mathrm{u} / \mu \mathrm{l}$ Taq-E and the total reaction volume was raised to $25 \mu \mathrm{l}$ using deionized water. Bcl-xl primer sequences were: upstream 5'-GGCAACCCATCCTGGCACCT-3', downstream 5'-AGCGTTCCTGGCCCTTTCG-3', yielding predicted amplification product of $472 \mathrm{bp}$. Bcl-xs primer sequences were: upstream 5'-GAGGGAGGCAGGCGACGAGTTT-3', downstream 5'-ATGGCGGCTGGACGGAGGAT-3', yielding predicted amplification product of $216 \mathrm{bp}$. $\beta$-actin primer sequences were: upstream 5'-GTGGGGCGCCCCAGGCACCA-3, downstream 5'-CTCCTTAATGTCACGCACGATTTC-3', yielding predicted amplification product of $498 \mathrm{bp}$. $\beta$-actin was used as internal control to normalize different reactions. PCR reaction was performed on an thermocycler (PTC-100 ${ }^{\mathrm{Tm}}$, USA). Amplification conditions for $\mathrm{Bcl}-\mathrm{xl}$ were: initial denaturation at $94^{\circ} \mathrm{C}$ for $3 \mathrm{~min}$, then proceeding with the following reaction conditions: a total of 35 cycles of denaturation at $94^{\circ} \mathrm{C}$ for $45 \mathrm{~s}$, annealing at $59^{\circ} \mathrm{C}$ for $45 \mathrm{~s}$, and extension at $72^{\circ} \mathrm{C}$ for $60 \mathrm{~s}$ before final extension at $72^{\circ} \mathrm{C}$ for $7 \mathrm{~min}$. As for Bcl-xs, the process included: initial denaturation at $94^{\circ} \mathrm{C}$ for $3 \mathrm{~min}$, then proceeding with the following reaction conditions: a total of 35 cycles of denaturation at $94^{\circ} \mathrm{C}$ for $40 \mathrm{~s}$, annealing at $60^{\circ} \mathrm{C}$ for $60 \mathrm{~s}$, and extension at $72^{\circ} \mathrm{C}$ for $60 \mathrm{~s}$, before final extension at $72^{\circ} \mathrm{C}$ for $7 \mathrm{~min} .5 \mu \mathrm{l}$ PCR product was subjected to $2 \%$ agarose gel electrophoresis $(150 \mathrm{v})$ for 60 min and stained with ethidium bromide. RT-PCR amplification product was then observed under UV light. ФX174Hinc II (TAKARA Co.) was included as the standard for relative molecular size. 1D KodaK image analysis software was used to observe and capture images. Optical density $(A)$ ratio of target gene and $\beta$-actin RT-PCR amplification products was calculated to determine the relative mRNA content of the target gene.

\section{Western-blot assay to determine the expressions of $\mathrm{BCl}-\mathrm{xl}$ and $\mathrm{BCl}-\mathrm{xs} / \mathrm{l}$ protein}

Cytosolic protein was extracted and sample OD values were determined by phenol reagent assay $(0.305 \sim 1.254)$. All samples were adjusted to equal concentration and sampling buffer was added. Total of 40 ug protein was loaded onto $10 \%$ polyacrylamide gel for $2 \mathrm{~h}$ electrophoresis and $\beta$-actin was used as loading control. After electric transferring, membrane was washed with TBS once, blocked by TBS containing 5\% (v/v) skim milk overnight and then washed with TTBS for 3 times, $5 \mathrm{~min}$ for each wash. Mouse anti-human Bcl-xl monoclonal antibody and mouse anti-human Bcl-xs/l monoclonal antibody were added (1:500 dilution for both antibodies in TTBS containing 1\% BSA), before 2 hours of incubation at room temperature. Next, membranes were washed by TTBS for 3 times and horseradish peroxidase-labeled mouse anti-rabbit IgG secondary antibody was added (1:500 dilution), The whole setup was incubated at room temperature for $1 \mathrm{~h}$ and washed by TTBS for 3 times, $5 \mathrm{~min}$ for each and finally washed by TBS for $5 \mathrm{~min}$. An automatic electrophoresis gel image analysis system (Chemi Imageer 5500) was used to analyze optical intensities of the protein bands. The equation of relative optical density $(A)=$ optical density of the target protein/optical density of actin, was used to perform semi-quantitative analysis.

\section{Statistical analysis}

SPSS13.0 statistical software was used to perform unpaired $t$-test, one-way ANOVA and correlation analysis. $P<0.05$ was set as the criteria for statistical significance. 


\section{Results}

Expressions of $\mathrm{Bcl}-\mathrm{xl}$ and $\mathrm{Bcl}-\mathrm{xs}$ mRNA in different types of endometrial tissues

RT-PCR result showed that tissues of expressed Bcl-xl mRNA in order from low to high levels Bcl-xl mRNA expressions were normal endometrium, simple hyperplasia endometrial tissue, atypical hyperplasia endometrial tissue, and endometrial carcinoma tissue (Fig. 1). Although level of Bcl-xl mRNA was slightly unregulated in simple hyperplasia endometrial tissue, it was not significantly different than that of normal endometrial tissue $(t=-1.51, P>0.05)$. In addition, no significant difference was detected between Bcl-xl mRNA level of atypical hyperplasia endometrial tissue and that of normal endometrium $(t=0.90, P>0.05)$. On contrary, Bcl$\mathrm{xl}$ expression in endometrial carcinoma tissue was significantly higher than in normal endometrial tissue $(t=$ 15.44, $P<0.05)$. Expression of Bcl-xl mRNA was not correlated with clinical staging, myometrial invasion and lymph node metastasis of the endometrial carcinoma, but correlated with histological grade $(\mathrm{F}=5.33, P=$ 0.02) (Table 1).

Furthermore, tissues of expressed Bcl-xl mRNA in order from low to high levels Bcl-xs mRNA levels were normal endometrium, simple hyperplasia endometrial tissue, atypical hyperplasia endometrial tissue and endometrial carcinoma tissue (Fig. 2). Although its expression was slightly elevated in simple hyperplasia endometrial tissue, no significant difference was detected compared to normal endometrial tissue $(t=$ $1.80, P>0.05)$. On contrary, its expression was significantly different between atypical hyperplasia endometrial tissue and normal endometrium $(t=5.17, P<0.05)$. In addition, Bcl-xs expression in endometrial carcinoma tissue was significantly higher than that in normal endometrium $(t=6.88, P<0.05)$ (Table 1$)$. Expression level of Bcl-xs mRNA was correlated with clinical staging and lymph node metastasis of the endometrial carcinoma, but not related to myometrial invasion and pathological staging.

\section{Expressions of $\mathrm{BCl}-\mathrm{xl}$ and $\mathrm{Bcl}-\mathrm{xs} / \mathrm{l}$ protein in different types of endometrial tissues}

Immunoblotting results showed that $\mathrm{Bcl}-\mathrm{xl}$ protein expression had matched pattern with expression of Bclxl mRNA in different types of endometrial tissues, For example, these two were positively correlated $(r=0.44$, $P=0.015)$. In other words, expressions of these two proteins were relatively low in normal endometrial tissue, while elevated expression could be detected in both simple hyperplasia and atypical hyperplasia endometrial tissues (Fig. 3). In addition, expressions of Bcl-xl and Bcl-xs/l proteins did not show a significant difference between simple hyperplasia and normal endometrial tissues $(t=-0.61, P>0.05)$ and the expression in atypical hyperplasia endometrial tissue was not significantly different from that in normal endometrial tissue $(t=-0.61$, $P>0.05)$. Expressions of $\mathrm{Bcl}-\mathrm{xl}$ and $\mathrm{Bcl}-\mathrm{xs} / \mathrm{l}$ proteins were further upregulated in endometrial carcinoma tissue to a level significantly different from that of normal endometrial tissue $(t=-2.22, P=0.04)$. Furthermore, expression of $\mathrm{Bcl}-\mathrm{xl}$ protein correlated with pathological staging of the tissue sample (see Table 2). Trend of Bcl$\mathrm{xs} / \mathrm{l}$ protein expressions in different types of endometrial tissues matched that of Bcl-xs mRNA expression. Specifically, no significant difference was found in Bcl-xs/l protein between simple hyperplasia and normal endometrial tissues $(t=0.33, P=0.75)$. However, significant differences of $\mathrm{Bcl}-\mathrm{xs} / \mathrm{l}$ expression were detected between normal endometrial tissue and atypical hyperplasia endometrial tissue $(t=2.42, P=0.04)$, as well as between normal endometrial tissue and endometrial carcinoma tissue $(t=4.14, P=0.00)$ (Fig. 4). Expression of $\mathrm{Bcl}-\mathrm{xs} / \mathrm{l}$ protein did not correlated with degree of myometrial invasion and pathological staging, but significantly correlated with clinical staging and lymph node metastasis of the sample (see Table 2).

\section{Correlation analysis between $\mathrm{Bcl}-\mathrm{xl}$ and $\mathrm{Bcl}-\mathrm{xs}$}

Correlation analysis identified a negative correlation between Bcl-xl gene and Bcl-xs gene in different types

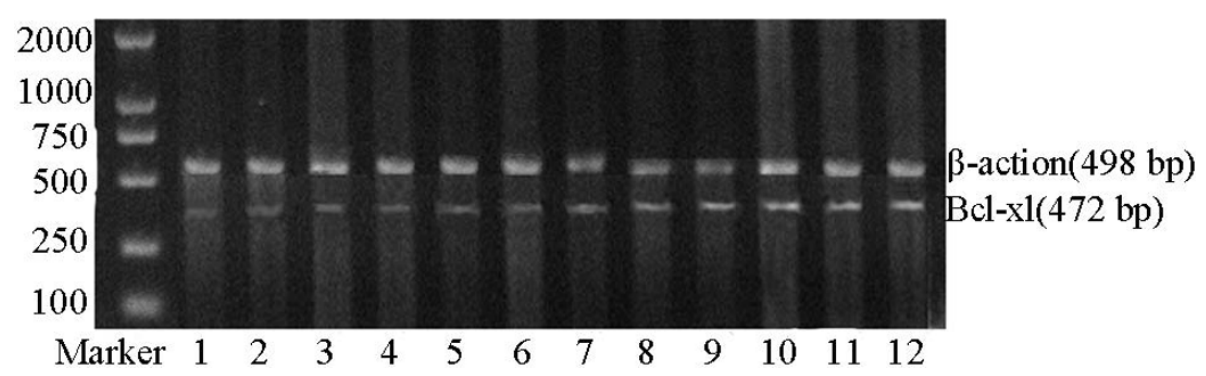

Figure 1 Bcl-xl mRNA(RT-PCR). 1, 2: Normal endometrium; 3, 4: Simple hyperplasia endometrial tissue, 5, 6: Atypical hyperplasia endometrial tissue; 7 12: Endometrial carcinoma tissue. 
Table 1 Contents of Bcl-xl and Bcl-xs mRNA in different types of endometrial tissue and correlation with pathological parameters of the endometrial carcinoma

\begin{tabular}{|c|c|c|c|c|}
\hline \multirow[t]{2}{*}{ Classification } & \multicolumn{2}{|c|}{ Bcl-xl mRNA expression } & \multicolumn{2}{|c|}{ Bcl-xs mRNA expression } \\
\hline & $\chi \pm S$ & $P$ value & $\chi \pm S$ & $P$ value \\
\hline Normal endometrium & $0.35 \pm 4.37$ & & $0.93 \pm 3.05$ & \\
\hline Simple hyperplasia & $0.38 \pm 3.25$ & 0.13 & $0.89 \pm 2.00$ & 0.12 \\
\hline Atypical hyperplasia & $0.37 \pm 3.93$ & 0.38 & $0.68 \pm 0.10$ & 0.00 \\
\hline Endometrial carcinoma & $0.75 \pm 0.13$ & 0.00 & $0.49 \pm 0.14$ & 0.00 \\
\hline \multicolumn{5}{|c|}{ Degree of Pathological Differentiation } \\
\hline Well-differentiated & $0.85 \pm 7.23$ & & $0.52 \pm 0.14$ & \\
\hline Moderately-differentiated & $0.70 \pm 7.60$ & $F=5.33$ & $0.45 \pm 0.16$ & $F=0.40$ \\
\hline Poorly-differentiated & $0.70 \pm 1.44$ & $P=0.02$ & $0.48 \pm 7.57$ & $P=0.68$ \\
\hline \multicolumn{5}{|l|}{ Clinical Staging } \\
\hline Stage I & $0.74 \pm 0.15$ & & $0.55 \pm 7.67$ & \\
\hline Stage II & $0.79 \pm 0.10$ & $F=0.57$ & $0.41 \pm 2.83$ & $F=30.87$ \\
\hline Stage III & $0.82 \pm 0.15$ & $P=0.58$ & $0.21 \pm 7.77$ & $P=0.00$ \\
\hline \multicolumn{5}{|l|}{ Lymph Node Metastasis } \\
\hline No & $0.82 \pm 0.16$ & $F=2.31$ & $0.51 \pm 9.16$ & $F=0.64$ \\
\hline Yes & $0.79 \pm 0.10$ & $P=0.73$ & $0.25 \pm 6.70$ & $P=0.00$ \\
\hline \multicolumn{5}{|c|}{ Depth of Myometrial Invasion } \\
\hline 0 & $0.82 \pm 7.26$ & & $0.58 \pm 7.07$ & \\
\hline$\leq 1 / 2$ & $0.76 \pm 0.11$ & $F=3.22$ & $0.45 \pm 0.16$ & $F=1.73$ \\
\hline$>1 / 2$ & $0.64 \pm 4.73$ & $P=0.07$ & $0.45 \pm 6.03$ & $P=0.22$ \\
\hline
\end{tabular}

of endometrial tissues $(\mathrm{r}=-0.76, \mathrm{P}=0.00)$. Bcl-xl protein was negatively correlated with expression of Bcl-xs/l protein $(\mathrm{r}=-0.39, P=0.04)$ and Bcl-xs gene was positively correlated with $\mathrm{Bcl}-\mathrm{xs} / \mathrm{l}$ protein expression $(\mathrm{r}=$ 0.73, $P=0.00)$.

\section{Discussion}

As a member of Bcl-2 gene family, role of Bcl-x in the development and progression of tumors has received more and more attentions. Bcl-x gene was cloned by Boise[8] in 1993 by screening a chicken lymphocyte cDNA library using mouse Bcl-2 cDNA as the probe. $\mathrm{Bcl}-\mathrm{x}$ has dual regulatory roles after activation. It is localized at 20q11.21 and a different splicing site at the 5' terminus of its $1^{\text {st }}$ mRNA exon leads to two fragments: a longer fragment $\mathrm{Bcl}-\mathrm{xl}$ and a shorter fragment $\mathrm{Bcl}-\mathrm{xs}$.

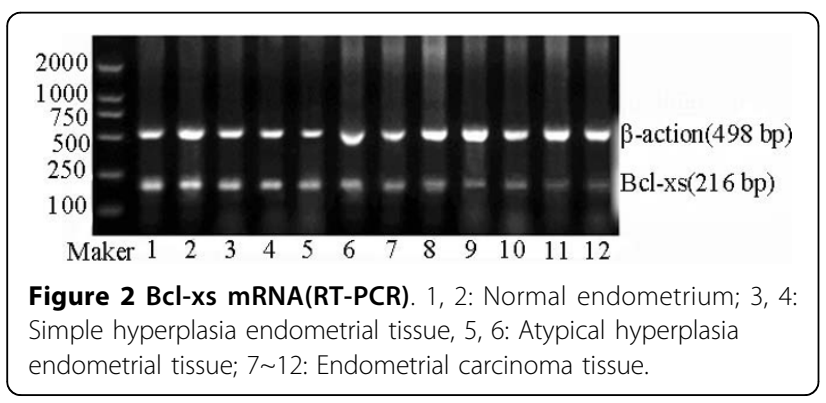

In recent years, expression of $\mathrm{Bcl}-\mathrm{x}$ gene products (Bcl$\mathrm{xl}$ and $\mathrm{Bcl}-\mathrm{xs})$ in some tumors has been reported in domestic and foreign studies. However, the expression status in endometrial carcinoma tissue has rarely been characterized yet.

Expression of $\mathrm{Bcl}-\mathrm{xl}$ in endometrial carcinoma tissue and the significances

Bcl-xl contains 241 amino acids and BH1-BH4 4 homologous sequences. Its sequence is $43 \%$ identical to that of Bcl-2 and their functions are similar too. Bcl-xl could inhibit cell apoptosis through forming heterodimer with Bax in cytosol. Studies found that Bcl-xl could inhibit apoptosis in a Bcl-2-independent manner. It could inhibit cell apoptosis mediated by many apoptosis-inducing

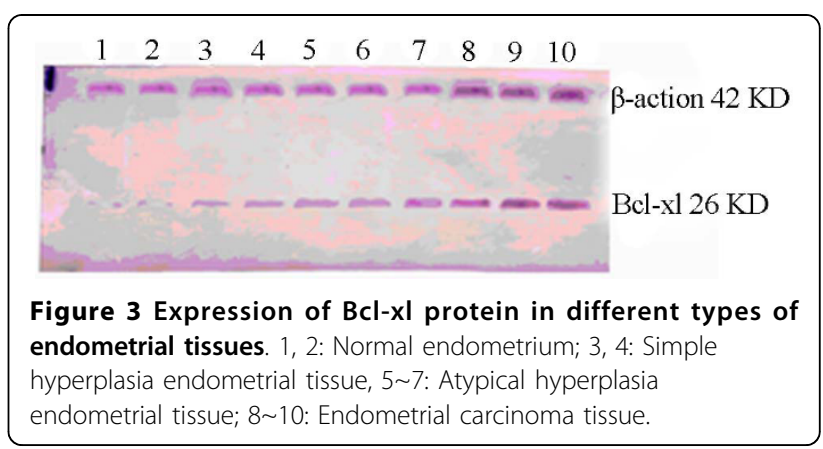


Table 2 Contents of $\mathrm{BCl}-\mathrm{xl}$ and $\mathrm{Bcl}-\mathrm{xs} / \mathrm{I}$ protein in different types of endometrial tissue and correlation with pathological parameters of the endometrial carcinoma

\begin{tabular}{|c|c|c|c|c|}
\hline \multirow[t]{2}{*}{ Classification } & \multicolumn{2}{|c|}{ Bcl-xl protein expression } & \multicolumn{2}{|c|}{ Bcl-xs/l protein expression } \\
\hline & $\chi \pm S$ & $P$ value & $\chi \pm S$ & $P$ value \\
\hline Normal endometrium & $41.00 \pm 21.05$ & & $105.60 \pm 33.05$ & \\
\hline Simple hyperplasia & $49.00 \pm 11.36$ & 0.57 & $96.00 \pm 50.48$ & 0.75 \\
\hline Atypical hyperplasia & $49.00 \pm 11.36$ & 0.56 & $73.00 \pm 4.47$ & 0.04 \\
\hline Endometrial carcinoma & $90.88 \pm 48.33$ & 0.04 & $54.50 \pm 18.49$ & 0.00 \\
\hline \multicolumn{5}{|c|}{ Degree of Pathological Differentiation } \\
\hline Well-differentiated & $109.29 \pm 39.06$ & & $57.71 \pm 22.33$ & \\
\hline Moderately-differentiated & $71.50 \pm 13.53$ & $F=4.65$ & $56.50 \pm 17.81$ & $F=0.32$ \\
\hline Poorly-differentiated & $56.67 \pm 17.21$ & $P=0.03$ & $46.67 \pm 4.04$ & $P=0.74$ \\
\hline \multicolumn{5}{|l|}{ Clinical Staging } \\
\hline Stage I & $85.17 \pm 50.83$ & & $61.17 \pm 16.03$ & \\
\hline Stage II & $108.00 \pm 48.08$ & $F=0.30$ & $45.50 \pm 2.12$ & $F=4.02$ \\
\hline Stage III & $108.00 \pm 52.33$ & $P=0.74$ & $30.50 \pm 6.36$ & $P=0.04$ \\
\hline \multicolumn{5}{|l|}{ Lymph Node Metastasis } \\
\hline$\overline{\text { No }}$ & $88.43 \pm 49.33$ & $F=0.06$ & $55.43 \pm 21.58$ & $F=0.95$ \\
\hline Yes & $108.00 \pm 52.33$ & $P=0.61$ & $30.00 \pm 5.66$ & $P=0.02$ \\
\hline \multicolumn{5}{|c|}{ Depth of Myometrial Invasion } \\
\hline 0 & $76.80 \pm 18.78$ & & $65.60 \pm 19.92$ & \\
\hline$\leq 1 / 2$ & $86.00 \pm 38.58$ & $F=1.13$ & $52.25 \pm 18.55$ & $F=1.34$ \\
\hline$>1 / 2$ & $127.33 \pm 94.99$ & $P=0.35$ & $46.67 \pm 2.52$ & $P=0.30$ \\
\hline
\end{tabular}

factors, which was far upstream in regulation of apoptosis. Bcl-xl protein was highly expressed in some tumors with low level of Bcl-2. Some researchers believed that Bcl-xl protein might have substituted the function of Bcl-2 in some tumors. Under certain condition, this protein has stronger apoptosis-inhibitory effect over Bcl-2, indicating the key role of Bcl-xl in the process of cell transformation.

Studies showed that tumor cell apoptosis could be induced by lowering the Bcl-xl expression in human prostate cancer tissue[9]. Furthermore, researches demonstrated that induction of tumor cell apoptosis could be achieved through inhibiting the expression of Bcl-xl in malignant pleural mesothelioma[10]. Boehmdenf et al. [11]also showed that Bcl-xl expression in

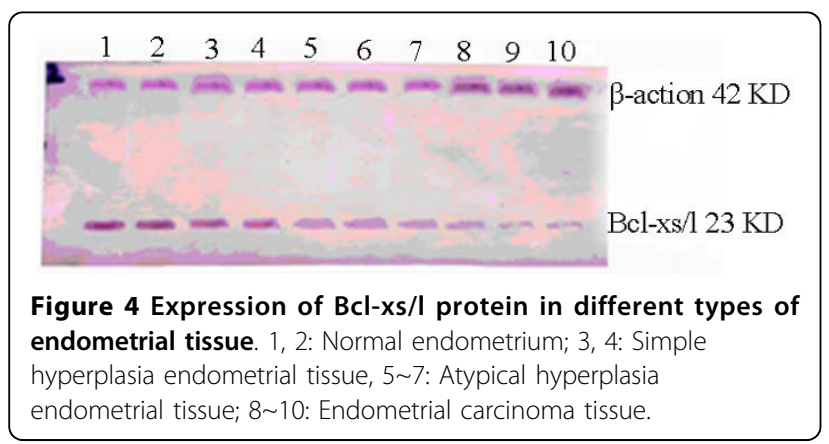

head and neck squamous cell carcinoma was significantly different among different types of pathological grading, while the expression of $\mathrm{Bcl}-\mathrm{xl}$ protein in human prostate cancer specimens was closely correlated with the Gleason scoring and metastasis of human prostate cancers[12]. Therefore, Bcl-xl plays an important role in pathogenesis of tumor as an antiapoptotic factor, and chemotherapy-resistance of the tumor cell may be associated with high level of Bcl-xl expression $[13,14]$.

Our study found that expressions of Bcl-xl mRNA and protein were slightly increased in simple hyperplasia and atypical hyperplasia endometrial tissues, while significantly increased in endometrial carcinoma tissue. In addition, $\mathrm{Bcl}-\mathrm{xl}$ expression was correlated with the pathological grading of endometrial carcinoma, suggesting that elevation in $\mathrm{Bcl}-\mathrm{xl}$ disrupted the regulation of signal transduction and normal gene expression, while it led to abnormal endometrial cell proliferation differentiation and eventually endometrial carcinoma. Therefore, we concluded that apoptotic inhibition caused by abnormal Bcl-xl expression might be one of the pathogenetic mechanisms of endometrial carcinoma, and this abnormal expression might also be associated with the malignant behaviors of endometrial carcinoma. 


\section{Expressions of $\mathrm{Bcl}-\mathrm{xs} \mathrm{mRNA}$ and $\mathrm{Bcl}-\mathrm{xs} / \mathrm{l}$ protein in endometrial carcinoma and the significances}

Bcl-xs has 63 amino acids less than Bcl-xl (BH1 and $\mathrm{BH} 2$ region). Its function is similar to that of $\mathrm{Bax}$, which is to inhibit Bcl-2 activity and promote cell apoptosis[4]. Sumantran et al. [5] used adenoviruses as vector to introduce Bcl-xs into breast cancer cell line. Their results showed that adv-Bcl-xs transfection could induce tumor cell apoptosis. In 1996, Ealovega et al. [15]constructed a replication-deficient adenovirus as vector to transiently express Bcl-xs in MCF-7 human breast cancer cell line and nude mice breast cancer tissues. They found that Bcl-xs overexpression could induce apoptosis of MCF-7 cells. Further studies have shown that advBcl-xs could infect breast cancer cells in vitro or in vivo to induce growth inhibition and death of breast cancer cells. This inhibitory and pro-apoptotic effects were more prominent with increased virus titer and increased Bcl-xs gene copies carried by the virus[16]. Our results showed that expressions of Bcl-xs mRNA and Bcl-xs/l protein slightly decreased in normal and simple hyperplasia endometrial tissues, while significantly decreased in atypical hyperplasia and endometrial carcinoma tissues, suggesting that abnormal expressions of these two played important roles in the early stage of endometrial carcinoma development. It was possible that low-expression of Bcl-xs led to inhibition of apoptosis, and thus abnormal endometrial cells threatening the body function could not be eliminated, resulting in endometrial carcinoma.

\section{The correlation between expressions of $\mathrm{Bcl}-\mathrm{xl}$ and $\mathrm{Bcl}-\mathrm{xs}$ in different types of endometrial tissues}

$\mathrm{Bcl}-\mathrm{xs}$ can form heterodimer with Bcl-xl. Ratio of these two affects the sensitivity and resistance of cells to variety of apoptotic factors and determines the activity of caspases, which are the final pathway for apoptosis in many different cells. Many Bcl-2 gene family members form a system with other members to modulate apoptosis, especially Bcl-2, Bcl-xs and Bax. Qiang Wang et al. [17] used in situ hybridization to test the expression statuses of $\mathrm{Bcl}-\mathrm{xl}$ and $\mathrm{Bcl}-\mathrm{xs}$ in postischemic brain tissue undergoing mild hypothermia treatment. They confirmed that ratio between $\mathrm{Bcl}-\mathrm{xl}$ and Bcl-xs concentrations determined whether apoptosis would occur or not. The expression of Bcl-xl and Bcl-xsm in different types of endometrial tissues were negatively correlated. We speculate that it might be $\mathrm{Bcl}-\mathrm{xs}$ not $\mathrm{Bcl}-\mathrm{xl}$ expression that is dominant in normal endometrial tissue. With progression of endometrial lesion, Bcl-xl expression increased while Bcl-xs expression decreased gradually. When Bcl-xl expression becomes dominant, endometrial carcinoma will be induced. The ratio between these two has certain impact on the development of endometrial cancer.

Since no specific Bcl-xs antibody is available now, we could not detect its expression directly using Western blot. In our study, we used $\mathrm{Bcl}-\mathrm{xs} / \mathrm{l}$ antibody that recognized a common motif of Bcl-xl and Bcl-xs, and primarily the motif in Bcl-xs. Our result suggested that expression of $\mathrm{Bcl}-\mathrm{xs} / \mathrm{l}$ was low in endometrial lesion tissue of high $\mathrm{Bcl}-\mathrm{xl}$ expression, implying low expression of Bcl-xs in these tissues.

In summary, our results suggested that abnormal elevation of $\mathrm{Bcl}-\mathrm{xl}$ expression and abnormal decrease of $\mathrm{Bcl}-\mathrm{xs}$ expression played an important role in the development of endometrial carcinoma. When malignant biological behaviors of endometrial carcinoma developded, $\mathrm{Bcl}-\mathrm{xs}$ gene expression was significantly decreased, providing a new tumor marker for the early diagnosis of endometrial carcinoma. Further studies on the action mechanisms of Bcl-xl and Bcl-xs gene should provide new molecular targets for gene therapy of endometrial carcinoma.

\section{Acknowledgements}

This project was supported by funding from Liaoning Provincial Education Department and in collaboration with the Biochemical department and other relevant departments.

Funding: Program of Shenyang Science and Technology Bureau(080671)

\section{Author details}

'Department of Obstetrics \& Gynecology, Shengjing Hospital of China Medical University, Shenyang(110004), China. ${ }^{2}$ China Medical University, Shenyang(110004), China.

\section{Authors' contributions}

XM designed the study and carried out RT-PCR technique and the Westernblot assay. YZ participated in RT-PCR technique and drafted the manuscript. $Y L$ participated in the Western-blot assay. HL participated in its design and coordination. YH participated in the manuscript drafting and performed the statistical analysis. All authors read and approved the final manuscript.

\section{Competing interests}

The authors declare that they have no competing interests.

Received: 23 November 2009

Accepted: 23 February 2010 Published: 23 February 2010

\section{References}

1. Jemal A, Siegel R, Ward E: Cancer statistics, 2007. CA Cancer J Clin 2007, 57:43-66.

2. Druilhe A, Arock M, Goffl Le: Human eosinophils express BCL-2 family proteins modulation of Mcl-1 expression by IFN-gamma. Am J Respir Cell Mol Biol 1998, 18:315.

3. Kawatani $\mathrm{M}$, moto $\mathrm{M}$ : Deletion of the $\mathrm{BH} 1$ domain of $\mathrm{BCl}-2$ accelerates apoptosis by acting in a dominant negative fashion. Biol Chem 2003, 278:19732-19742.

4. Boise LH, Gonzalez-Garcia M, postema CE: Bcl-x, a bcl-2-related gene that functions as a dominant regulator of apoptotic cell death. Cell 1993, 74:579-608.

5. Sumantran VN, Ealovega MW, Nunez G: Over expression of Bcl-xs sensitives MCF-7 cells to chemotherapy induced apoptosis. Cancer Res 2005, 65:3507-3516. 
6. Chauhan MA, Velankar M, Brahmandam M: A novel bcl-2/bcl-x(I)/bcl-w inhibitor ABT-737 as therapy in multipl myeloman. Oncogene 2006, 52:3102-3109

7. Haynik DM, Prayson RA: Immunohistochemical Expression of bcl-2, bcl-x, and Bax in Follicular Carcinoma of the Thyroid. Appl Immunohistochem Mol Morphol 2006, 14:417-421.

8. Boise $\mathrm{LH}$, Thompson $\mathrm{CB}$ : $\mathrm{BCl}-\mathrm{X}(\mathrm{L})$ can inhibit apoptosis in cells that have under go Fasind- uces protease activation. Proc Natl Acad Sci USA 1997, 94:3759-3764.

9. Lee DH, Szczepanski M, Lee YJ: Role of Bax in quercetin-induced apoptosis in human prostate cancer cells. Biochem Pharmacol 2008, 75:2345-2355

10. Smythe WR, Mohuiddin I, Ozveran M: Antisense therapy for malignant mesothelioma with oligonucleotides targeting the $\mathrm{Bcl}-\mathrm{xl}$ gene product. Thorac Cardiovasc Surg 2002, 123:1191-1198.

11. Boehm A, Sen M, Seethala R: Combined Targeting of EGFR, STAT3, and Bcl-XL Enhances Antitumor Effects in Squamous Cell. Mol Pharmacol 2008, 69:3806-3816.

12. Castilla C, Congregado B, Chinchon D: BCl-xl is overexpressed in hormone-resistant prostate cancer and promotes survival of LNCaP cells via interaction with proapoptotic Bak. Endocrinology 2006, 147:4960-4967.

13. Zhan Q, Alamo I, Yu K: The Apoptosis associated $\gamma$-ray Response of BCl-xl Depends on Normal P53 Function. Oncogene 1996, 13:2287.

14. Reeve JG, Xiang J, Mortan J: Expression of Apotosis regulatory Genes in Lung Tumor Cell Lines: Relationship to P53 Expression and Rlevance to Acquired Drug Resistance. Br J Cancer 1996, 73:1193.

15. Ealovega MW, McGinnis PK: BCl-xs gene therapy induces apoptosis of human mammary tumors in nude mice. Cancer Res 1996, 56:1965-1969.

16. Fukunaga-Johnson N: BCL-XS adenovirus-mediated gene therapy approach sensitizes cancer cells to radiation-induced apoptosis. International Journal of Radiation Oncology 2006, 60:3809-3910.

17. Wang $Q$, Sun $Y-M$, Li T-S, Zhu Q-Q, Li J: Effects of mild hypothermia on the apoptosis of neurocyte and the expression of BCl-xl, BCl-xs and HSP70 mRNA after focal cerebral ischemia in rats. Chinese Journal of Physical Medicine and Rehabilitation 2005, 27:272-275.

doi:10.1186/1756-9966-29-14

Cite this article as: Ma et al:: Relevance of Bcl-x expression in different types of endometrial tissues. Journal of Experimental \& Clinical Cancer Research 2010 29:14.

\section{Submit your next manuscript to BioMed Central and take full advantage of:}

- Convenient online submission

- Thorough peer review

- No space constraints or color figure charges

- Immediate publication on acceptance

- Inclusion in PubMed, CAS, Scopus and Google Scholar

- Research which is freely available for redistribution

Submit your manuscript at www.biomedcentral.com/submit
Ciomed Central 